\title{
Abstract Rights versus Paper Rights under Article 9 of the Uniform Commercial Code
}

\author{
Robert Charles Clark ${ }^{\dagger}$
}

The documentary embodiment of a secured party's rights has intriguing and varying consequences in a number of situations governed by Article 9 of the Uniform Commercial Code. ${ }^{1}$ This article will explore some of these consequences and the broader questions they raise, and will suggest some hypotheses about the functional significance of documentation ${ }^{2}$ and alternatives to documentation in different branches of commercial life. For brevity, and to avoid confusion over the word "documentary," such embodiments of rights are referred to here by a phrase not found in the UCC, "paper rights."

The article will examine problems concerning four specific kinds of paper rights: promissory notes ${ }^{3}$ and stock certificates ${ }^{4}$ (defined by Article 9 as members of a larger class of paper rights called "instruments" ${ }^{\prime \prime}$ ), warehouse receipts ${ }^{6}$ (a part of the larger Article 9 class of

$\dagger$ Assistant Professor of Law, Yale University.

1. Hereinafter cited as the UCC or the Code or by section number only. All citations are to the 1972 official text unless otherwise indicated.

2. By "documentation" I mean the evidencing of rights in a paper form that rises to the level of a negotiable or quasi-negotiable instrument or document.

3. See $\$ 3-104:$

(1) Any writing to be a negotiable instrument within this Article must

(a) be signed by the maker or drawer; and

(b) contain an unconditional promise or order to pay a sum certain in money and no other promise, order, obligation or power given by the maker or drawer except as authorized by this Article; and

(c) be payable on demand or at a definite time; and

(d) be payable to order or to bearer.

(2) A writing which complies with the requirements of this section is

(d) a "note" if it is a promise other than a certificate of deposit.

(3) As used in other Articles of this Act, and as the context may require, the [following] terms [including]... "note" may refer to instruments which are not negotiable within this Article as well as to instruments which are so negotiable.

4. See $\$ 8-102(1)(a)$, quoted in note 39 infra.

5. See $\$ 9-105(1)(\mathrm{i})$ :

"Instrument" means a negotiable instrument (defined in Section 3-104), or a security (defined in Section 8-102) or any other writing which evidences a right to the pay. ment of money and is not itself a security agreement or lease and is of a type which is in ordinary course of business transferred by delivery with any necessary indorsement or assignment....

6. See $\$ 1-201(45)$ :

"Warehouse receipt" means a receipt issued by a person engaged in the business of storing goods for hire. 
"documents"7), and "chattel paper"8 (a broad Article 9 classification). Each of these pieces of paper puts its holder in a legal position somewhat different from that of the mere possessor of the underlying or corresponding unembodied form of the right; the holder has a right which has been "concretized" in the paper, rather than remaining an abstract right to the property.

In the case of instruments like promissory notes or stock certificates, the corresponding unembodied right is usually an intangible, a right which does not represent an interest in particular, concrete personal property but which represents instead an interest, defined by a formula or a set of rules, in a legally recognizable locus of value. Consider the situation which gives rise to a promissory note. A consumer's obligation to pay money to a retailer may be called an account receivable or, in UCC terminology, an account. ${ }^{\circ}$ The obligation may of course be satisfied by any of the money, or indirectly by any of the property, owned by the consumer. ${ }^{10}$ Furthermore, the retailer may treat the account as intangible property and may sell or hypothecate it. On the other hand, the consumer's obligation may be embodied in more or less definite paper form, as when he gives the retailer a promissory note. The retailer then has a paper right rather than an abstract right.

The shareholder in a corporation finds himself in a similar situation. Traditionally, a shareholder's interest has been represented by a

7. See $\$$ 9-105(1)(f):

"Document" means document of title as defined in the general definitions of Article

1 (Section 1-201), and a receipt of the kind described in subsection (2) of Section 7-201 .....

See $\$ 1-201(15)$ :

"Document of title" includes bill of lading, dock warrant, dock receipt, warchouse receipt or order for the delivery of goods, and also any other document which in the regular course of business or financing is treated as adequately evidencing that the person in possession of it is entitled to receive, hold and dispose of the document and the goods it covers. To be a document of title a document must purport to be issued by or addressed to a bailce and purport to cover goods in the bailee's possession which are either identified or are fungible portions of an identified mass.

8. See $\$ 9.105(1)(b)$ :

"Chattel paper" means a writing or writings which evidence both a monetary obligation and a security interest in or lease of specific goods, but a charter or other contract involving the use or hire of a vessel is not chattel paper. When a transaction is evidenced both by such a security agreement or a lease and by an instrument or series of instruments, the group of writings taken together constitutes chattel paper.

9. See $\$ 9-106$ :

"Account" means any right to payment for goods sold or leased or for services rendered which is not evidenced by an instrument or chattel paper, whether or not it has been earned by performance.

10. That is, the retailer has a claim against the total pool of his debtor's nonexempt resources. Of course, specific items of property owned by the debtor may be subject to claims that take precedence over the retailer; other creditors and claimants may have priority in the residual pool of assets over retailer's claim in that pool; and the assemblage of claimants on a par with the retailer may have claims which in toto greatly exceed the value of the pool of resources left over for them so that, in a bankruptcy proceeding, each would receive a partial but pro rata satisfaction of his claim. 
piece of paper, the stock certificate. However, certificates are not required by the laws of all states, ${ }^{11}$ and it is quite normal for a shareholder in some types of public corporations to possess a shareholder interest without there being any corresponding certificate. ${ }^{12}$ In this article I will refer to such an unembodied shareholder interest as a "share" in contrast to a "stock certificate."13

In the case of the paper rights classed as documents (including warehouse receipts) and chattel paper, the corresponding abstract (i.e., not paperized) right or entitlement is usually in specific tangible property, or at least in a defined quantity of tangible property that is "fungible"14 with similar property. Thus, a secured party may possess a nondocumented interest in specific, tangible goods of a debtor. (It is rare that such a secured party's interest would not be referred to in a writing of some sort, but often enough the writing will not rise to the dignity of a document in the legal sense.) When the debtor of such a secured party bails the particular goods with a warehouseman, the interests of both the debtor and the secured party may become embodied in a warehouse receipt and may thus become a paper right. Similarly, a secured party's security interest in goods may be abstract or it may be represented by what the UCC refers to as "chattel paper."15

In order to test the significance of possessing a paper right instead of a mere abstract right, the following section will explore certain priority problems arising between possessors of the two kinds of rights. ${ }^{16}$ The general paradigm is as follows: Debtor, who has an in-

11. See, e.g., Mass. Gen. Laws ANn. ch. 156B (1970) (general statutory provisions governing Massachusetts business corporations nowhere require that shares be evidenced by certificates). The inference from $\$ 27$ of chapter $156 \mathrm{~B}$, which states that each stockholder "shall be entitled to a certificate stating the number and the class and the designation of the series, if any, of the shares held by him," is that shareholders may, at their option, obtain certificates but need not do so.

12. Many mutual funds, including funds which specialize in money market instruments and advertise the ease and quickness with which shareholders can retrieve their investments, do not in fact issue stock certificates representing shares sold unless requested to do so by the particular shareholder who owns the shares. See, e.g., Dreyfus Liquid Assets, Inc., Prospectus, May 15, 1974, at 8; The Johnston Mutual Fund, Inc., Prospectus, May 1,1974 , at 11. The former fund is incorporated in Maryland (see Dreyfus Prospectus at 10); the latter, in New York (see Johnston Prospectus at 2).

13. In common parlance, the term "share", is ambiguous and is often taken to mean a certificate as well as the interest it represents. For purposes of clarity, the term as used here should not be taken to connote a certificate.

14. See $\$ 1-201(17)$ :

"Fungible" with respect to goods or securities means goods or securities of which any unit is, by nature or usage of trade, the equivalent of any other like unit.

15. See note 8 supra (definition of chattel paper). For a discussion at length of priority problems involving chattel paper, see Levie, Security Interests in Chattel Paper, 78 YaLE L.J. 935 (1969).

16. In some of the situations discussed, the priority problem is commercially insignificant. This article is, however, largely concerned with attempting to achieve a more basic theoretical understanding of the role of "paperization" of rights. 
terest in property, either tangible or intangible, deals first with a party who obtains a security interest in an abstract right. This first secured party properly perfects his interest by following the procedures set forth in Article 9. Debtor then wrongfully converts the abstract right into a paper right and pledges it to an innocent second secured party. The question then arises as to which secured party has priority in Debtor's right. ${ }^{17}$ This paradigm will be examined using each of the four specific pairs of rights mentioned earlier: account versus note; share versus stock certificate; interest in goods versus warehouse receipt; and interest in goods versus chattel paper.

The resolution of the basic priority paradigm is not the same in each of the four specific contexts. In the account versus note situation,

17. A common problem throughout the analyses in this article of specific situations is whether the transfer by the debtor in question to the second secured party is voidable as a fraudulent conveyance, either in bankruptcy or in a proceeding or action sanctioned by state fraudulent conveyance laws. Under $\$ 67 d$ of the Bankruptcy Act, 11 U.S.C. $\$ 107$ (d) (1970), it is fairly clear that in each example the Debtor's granting a security interest to the second secured party is a fraudulent conveyance, since it is by hypothesis made with the "actual intent... to... defraud" referred to in $\$ 67 \mathrm{~d}(2)(\mathrm{d})$. However, not everything that is properly characterized as a fraudulent conveyance is voidable. The operative part of the federal provisions, $\$ 67 \mathrm{~d}(6)$, states that a transfer fraudulent against creditors having claims provable under the Bankruptcy Act shall be null and void against the trustee in bankruptcy "except as to a bona fide purchaser, lienor, or obligee for a present fair equivalent value." In all of the examples discussed in this article, the second secured party acts in good faith and gives a contemporaneous, fair advance in return for the security interest he receives. His right thus cannot be voided on the basis of $\$ 67 \mathrm{~d}$; whether he has priority over the first secured party depends essentially on the provisions of the UCC. In this respect, the large number of state fradudulent conveyance laws which adopt a version of the Uniform Fraudulent Conveyance Act (which is quite similar to $\$$ 67d) would lead to the same result. See 9B UNIFORM LAWs ANN. 70 (1966) (lists states adopting Uniform Fraudulent Conveyance $\mathrm{Act}$ ).

The phrase in the "except" clause of $\$ 67 \mathrm{~d}(6)$, "present fair equivalent value" (emphasis added), may lead one to wonder whether a secured party invoking the exception must have made an advance equal in amount to the value of the collateral. Such an interpretation would seem absurd, in view of customary collateral coverage ratios and the dual definition of "fair" consideration set forth in $\$ 67 \mathrm{~d}(\mathrm{I})(\mathrm{e})$ : In outright purchase situations, the test of fair consideration is equivalence of value between the transferred property and the consideration given for it, but in a secured transaction, consideration is fair when the debt in question is not "disproportionately small" in relation to the value of the collateral. Furthermore, $\S 67 \mathrm{~d}(6)$ contains a proviso that "such purchaser, lienor, or obligee, who without actual fraudulent intent has given a consideration less than fair, as defined in this stubdivision, for such transfer, lien, or obligation, may retain the property, lien, or obligation as securty for repayment." This proviso was obviously written with the outright purchase situation principally in mind-if the transferor had a fraudulent intent or if the transfer were otherwise a fraudulent conveyance, but if the transferee was without fraudulent intent in giving less than fair consideration, the transferee, though he cannot keep the property, nevertheless has the right to get his money back, and this right is secured by the transferred property. The proviso is not restricted to the outright purchase situation, however, and it seems to imply clearly that, even if in the situations discussed in this article the second secured party were not regarded as giving "present fair equivalent value" (because few secured parties would ever accept collateral whose value only equals the amount of their loans), the second secured party would still have the right to retain his status as secured party as long as he was without actual fraudulent intent.

Therefore, fraudulent conveyance problems do not form a decisive element in the determination of rights as between the first and second secured party in the situations analyzed here as specific versions of the priority problem paradigm. 
the secured party who is second in time to perfect has priority over the first; in the share versus stock certificate situation, the second secured party probably has priority; in the interest in goods versus warehouse receipt situation, the first secured party has priority if the goods were equipment in the hands of the debtor, but only arguably has priority if they were inventory; and in the interest in goods versus chattel paper situation, the first secured party will have priority under a blindly literal analysis of the Code.

In the first section of this article, I shall justify these conclusions by an interpretation and analysis of the relevant provisions of Article 9 of the UCC. In the second section, I shall attempt to justify the Code determinations in light of certain basic policy considerations. In the third section, I shall place the policy considerations themselves within a more systematic theoretical analysis of the legal devices used to mitigate the dysfunctions of the abstract holding of rights.

\section{Patterns of Priority}

\section{A. Account versus Note}

Suppose that Buyer buys goods from Dealer. No note is given; all that happens is that an account is created on which Buyer is the account debtor ${ }^{18}$ and Dealer is the obligee. Dealer then grants to Bank a security interest in all of Dealer's accounts in connection with a loan from Bank to Dealer. Bank perfects its interest by making a proper UCC filing of a financing statement. The statement covers all accounts and proceeds thereof. Without telling Bank, Dealer later requests that Buyer execute a demand note to evidence the account. After receiving the note, Dealer immediately pledges it to Finance Company in order to secure a contemporaneous loan from Finance Company to Dealer. Under Article 9, who has priority in Dealer's rights against BuyerBank or Finance Company? In order to answer this question, as well as the parallel questions raised in each of the other three specific situations discussed below, we must consider in each case two similar but different lines of analysis-one based principally on $\S 9-308(a)^{19}$

18. See $\$ 9-105(1)(a):$ "[T]he person who is obligated on an account, chattel paper or general intangible."

19. A purchaser of chattel paper or an instrument who gives new value and takes possession of it in the ordinary course of his business has priority over a security interest in the chattel paper or instrument

(a) which is perfected under Section 9-304 (permissive filing and temporary perfection) or under Section 9.306 (perfection as to proceeds) if he acts without knowledge that the specific paper or instrument is subject to a security interest; or 
and one based principally on $\S 9-309 .{ }^{20}$

Under $\S 9-308(a)$, which deals with the priority rights of certain purchasers of chattel paper or instruments, it is clear that Finance Company, which is a "purchaser"21 within the meaning of that section and has met the section's qualifications by giving new value for the note and taking possession of it in the ordinary course of its business, is intended to have priority over a security interest in the instrument which is perfected in ways specified in the section. The first of these is perfection under $\S 9-304,{ }^{22}$ which inter alia concerns "permissive fil-

(b) which is claimed merely as proceeds of inventory subject to a security interest (Section 9-306) even though he knows that the specific paper or instrument is subject to the security interest.

Section 9-308(b) does not lend itself to the kind of puzzling situation about which I am chiefly concerned. It states in cffect that chattel paper and note financers (discounters) who take possession of chattel paper or instruments generated by the dealer will prevail over inventory financers who claim such items as proceeds of the dealer's sale of inventory. See Associates Discount Corp. v. Old Freeport Bank, $421 \mathrm{~Pa} .609,220$ A.2d 621 (1966), where, in just such a basic factual situation, the bank inventory financer had used its leverage to get the dealer's customer to execute a second security agreement and make payments under it; the court held that the bank received the payments as constructive trustee for the finance company which had taken the original set of papers.

In the $\$ 9-308(b)$ sort of dispute, interesting problems may arise as to when the inventory is deemed to have been sold and thus converted into proceeds. See Chrysler Credit Corp. v. Sharp, 56 Misc. 2d 261, 288 N.Y.S.2d 525 (Sup. Ct. 1968), where an automobile dealer had entered into an agreement for the sale of an automobile to a customer, had obtained chattel paper as part of the consideration therefor, and had in effect repossessed the car before it left the dealer's possession. The inventory financer, a bank, seized and sold the car in order to apply the proceeds against the dealer's obligations to it. The court held that the car had already been sold at the time of scizure and therefore had to be viewed, not as inventory of the dealer, but as proceeds of chattel paper. The bank therefore lost the sales proceeds to the chattel paper financer, a finance company.

20. Nothing in this Article limits the rights of a holder in due course of a negotiable instrument (Section 3-302) or a holder to whom a negotiable document of title has been duly negotiated (Section 7-501) or a bona fide purchaser of a security (Section 8-301) and such holders or purchasers take priority over an earlier security interest even though perfected. Filing under this Article does not constitute notice of the security interest to such holders or purchasers.

21. Under $\S 1-201(32)$, "'Purchase' includes taking by sale, discount, negotiation, mortgage, pledge, lien, issue or re-issue, gift or any other voluntary transaction creating an interest in property." Under $\$ 1-201(33)$, "Purchaser' means a person who takes by
purchase."

22. (1) A security interest in chattel paper or negotiable documents may be perfected by filing. A security interest in money or instruments (other than instruments which constitute part of chattel paper) can be perfected only by the secured party's taking possession, except as provided in subsections (4) and (5) of this section and subsections (2) and (3) of Section 9-306 on proceeds.

-...

(4) A security interest in instruments or negotiable documents is perfected without filing or the taking of possession for a period of 21 days from the time it attaches to the extent that it arises for new value given under a written security agreement.

(5) A security interest remains perfected for a period of 21 days without filing where a secured party having a perfected security interest in an instrument, $a$ negotiable document or goods in possession of a bailee other than one who has issued a negotiable document therefor

(a) makes available to the debtor the goods or documents representing the goods for the purpose of ultimate sale or exchange or for the purpose of loading, unloading, storing, shipping, transshipping, manufacturing, processing or other- 
ing" and "temporary perfection." Bank could not, in our example, claim a perfected security interest in the note by virtue of either of these modes of perfection. ${ }^{23}$ Even if it could make such a claim, Finance Company would have priority over such a perfected security interest: as noted above, that is the point of $\S 9-308$ (a).

The other type of perfected interest over which Finance Company prevails by virtue of the section is an interest in the instrument perfected as to proceeds under $\S 9-306 . .^{24}$ The important question, then, is whether Bank is claiming a security interest in the note as proceeds, or whether there is some other sort of interest as to which Bank can assert a claim.

wise dealing with them in a manner preliminary to their sale or exchange, but priority between conflicting security interests in the goods is subject to subsection (3) of Section 9-312; or

(b) delivers the instrument to the debtor for the purpose of ultimate sale or exchange or of presentation, collection, renewal or registration of transfer.

23. Except when instruments are treated as part of chattel paper, see $\$ 9-304(1)$, quoted in note 22 supra (or when they are treated as "proceeds," a treatment discussed in text in the next paragraph), one never perfects as to them by filing, whether "permissive" or otherwise. Bank could therefore not claim a perfected security interest in the note as such by virtue of a filing as to the note, even if its security agreement with Debtor and its filed financing statement had both thrown in, out of an abundance of caution, the words "notes and other instruments" as part of the description of the collateral. Moreover (again excepting situations in which notes are treated as proceeds), the only kind of "temporary perfection" without possession that Bank might avail itself of would occur during a 21-day period starting when (a) Bank's nonpossessory security interest in the note "attaches" (see definition of that term at $\S 9-203(2)$ ), and then only to the extent that the security interest in the note arises for new value under a written security agreement, see $\$ 9.304(4)$; or (b) Bank, which already had a perfected security interest in the note (as by possession), "delivers" it over to the debtor for certain limited purposes, see $\$ 9.304(5)$. Since Bank, in our example, provided no new value to Debtor when Buyer made the note and Debtor received it and pledged it to Finance Company, and since Bank never delivered the note to anybody, for any purpose, Bank cannot claim a perfected security interest in the note under some theory of "temporary perfection" sanctioned by $\$ 9.304$.

24. Subsections (2) and (3) of $\$ 9-306$ state, regarding the perfection of proceeds:

(2) Except where this Article otherwise provides, a security interest continues in collateral notwithstanding sale, exchange or other disposition thereof unless the disposition was authorized by the secured party in the security agreement or otherwise, and also continues in any identifiable proceeds including collections received by the debtor.

(3) The security interest in proceeds is a continuously perfected security interest if the interest in the original collateral was perfected but it ceases to be a perfected security interest and becomes unperfected ten days after receipt of the proceeds by the debtor unless

(a) a filed financing statement covers the original collateral and the proceeds are collateral in which a security interest may be perfected by filing in the office or offices where the financing statement has been filed and, if the proceeds are acquired with cash proceeds, the description of collateral in the financing statement indicates the types of property constituting the proceeds; or

(b) a filed financing statement covers the original collateral and the proceeds are identifiable cash proceeds; or

(c) the security interest in the proceeds is perfected before the expiration of the ten day period.

Except as provided in this section, a security interest in proceeds can be perfected only by the methods or under the circumstances permitted in this Article for original collateral of the same type. 
Section 9-306(1) defines "proceeds" to include "whatever is received upon the sale, exchange, collection or other disposition of collateral or proceeds." 25 The account on which Buyer was the obligor was originally Bank's "collateral": one could argue that Dealer "disposed" of the account by demanding and receiving the note. Thus, it would appear that Bank's equitable interest in the note is an interest in proceeds, and is therefore subordinate to Finance Company's security interest by virtue of $\S 9-308(a)$, even though Bank's interest was first in time and was properly perfected.

Bank's only remaining line of argument against Finance Company would depend upon an assertion that Finance Company's security interest extends only to the note ${ }^{26}$ and not to the corresponding account. Bank would argue that the account perdures despite Dealer's wrongful procuring of the note, and that Bank is claiming priority in Dealer's abstract right against Buyer. This argument will work, of course, only if it can be said that the abstract right and the paper right can exist simultaneously. ${ }^{27}$ Unfortunately for Bank, definitional language in Article 9 implies that when Buyer gave his note the account was extinguished. Section 9-106 defines "account" to mean "any right to payment for goods sold or leased or for services rendered which is not evidenced by an instrument....28 This means that there cannot be an account in the UCG sense when the right to payment which would be referred to by that term is evidenced by an instrument such as a note. Since the resultant priority accorded Finance Company over the earlier perfecting and equally innocent Bank would thus appear to turn solely on the wording of a general purpose definition, it may be wondered whether the UCC draftsmen gave much explicit thought to the precise priority problem under discussion. As will be argued in the final section of this article, ${ }^{29}$ it is not at all obvious as a matter of original policy that Finance Company ought to prevail against Bank. ${ }^{30}$

25. See $\$ 9.306(1)$ (emphasis added).

26. Note that $\$ 9-308(a)$, quoted in note 19 supra, speaks only of priority "over a security interest in the chattel paper or instrument" as to which the purchaser has taken possession (emphasis added).

27. Note that acceptance of such an argument would mean that Buyer might be held doubly liable (to Bank on the account and to Finance Company on the note). Bank could, of course, argue that this is simply a problem that Buyer created for himself.

28. See $\$ 9.106$ (emphasis added).

29. See pp. 474-79 infra.

30. Bank can get some comfort out of the fact that it cannot be defrauded successfully by Dealer if the latter exacts a note from Buyer and transfers it to a finance company which is a cooperating affiliate of Dealer, a majority shareholder, or a creditor seeking satisfaction of a prior debt. This is because $\$$ 9-308(a) requires that the later secured party taking possession of the note must give new value, act in the ordinary course, and be without knowledge of Bank's security interest in order to prevail. See $\$$ 9-308(a), quoted in note 19 supra. To put the point generally, the second secured party 
Our second basic line of analysis of the priority problems proceeds from $\S 9-309 .{ }^{31}$ If Finance Company not only satisfies the requirements of $\S 9-308(a)$, but also qualifies as a holder in due course under $\S 3-302(1),{ }^{32}$ it can mount an argument based on $\S 9-309$, which states that nothing in Article 9 "limits the rights" of a holder in due course (or certain others) and that such holders and others "take priority over an earlier security interest even though perfected." 33 This provision is ambiguous, however, since the "earlier security interest" referred to might mean any earlier security interest whatsoever (yielding an absurd result), an earlier interest in the note (leaving the answer to our priority problem unsettled), an earlier interest in the note or in the right which the note came to evidence (answering the question in favor of Finance Company), or something else. ${ }^{34}$ However, since a secured party who qualifies as a holder in due course of a note would ordinarily qualify under $\$ 9-308(a),{ }^{35}$ the indeterminacy of $\S 9-309$ will not often pose a serious obstacle to resolution of the kind of priority problem raised by the example under discussion. ${ }^{36}$

will not have priority under certain circumstances which might tend to encourage or make possible collusion between the second secured party and the fraudulent debtor. My focus is not on such familiar conflict-of-interest situations, but on the harder problems posed by the paradigm in which both transferees are likely to be innocent.

31. Quoted in note 20 supra.

32. (1) $A$ holder in due course is a holder who takes the instrument

(a) for value; and

(b) in good faith; and

(c) without notice that it is overdue or has been dishonored or of any defense

against or claim to it on the part of any person.

33. See $\$ 9.309$, quoted in note 20 supra.

34. Failure to perceive this ambiguity, together with the knee jerk response one tends to make in favor of possessors of notes, may account for the decision in Citizens Valley Bank v. Pacific Materials Co., 263 Ore. 557, 503 P.2d 491 (1972), where the account versus note paradigm was resolved in favor of the notetaker with a simple, nonreflective citation of $\$ 9-309$. It is probable that most courts would follow suit.

35. A secured party might be a holder in due course of a note and yet not qualify under $\$ 9-308(a)$. For example, a wealthy individual who takes a note as part of an incidental lending transaction is not acting in the "ordinary course of his business" as required by $\$ 9-308(a)$. Such cases should be relatively infrequent.

36. It is interesting to consider the opposite relationship: whether, if Finance Company qualified for priority treatment under $\S 9-308(a)$, it would surcly qualify under $\S$ 9-309. If so, $\$ 9-308$ (a) would add anything only when the note is non-negotiable, e.g., the type of note referred to in $\$ 3-805$ (instruments not payable to bearer or to order). By definition no one could then be a holder in duc course of a negotiable instrument; $c f$. Appendix to UCC, $\$ 9.308$, Reasons for 1972 Change. Former $\$ 9-308$ was in fact directed only to purchasers of chattel paper and non-negotiable instruments. It was later realized that in some circumstances a holder of a negotiable instrument was less protected than a similarly situated holder of a non-negotiable instrument-for instance, where the holder of the negotiable instrument did not qualify as a holder in due course (who could invoke $\$ 9-309$ ) but could qualify under $\$ 9-308(a)$, were it applicable. The 1972 changes simply made $\$ 9.308$ applicable to such a holder, thus putting him in as good a legal position as the similarly situated holder of a non-negotiable instrument would be.

However, the non-negotiable note does not provide the only example in which a holder qualifying under $\$ 9-308$ (a) would not qualify under $\$ 9.309$. Finance Company in our example comes under $\$ 9$-308(a) because, as there prescribed, it gave new value, took possession in the ordinary course of its business, and acted "without knowledge that 


\section{B. Share versus Stock Certificate}

Imagine a mutual fund in a state that requires corporations organized under its laws to give shareholders stock certificates if they request them, but that does not absolutely require shares to be evidenced by certificates. The firm may very well decide, in order to reduce paper work and the expenses of its transfer agent, never to issue certificates unless. requested to do so by a particular shareholder. ${ }^{37}$ Suppose that such a fund issues 100 shares to Debtor and merely sends Debtor a notification of his registration on the books of the transfer agent as a shareholder of the firm. Debtor then grants a security interest in these shares to an unsophisticated wealthy individual, Lender, who loans Debtor money.

In a perfectly logical and straightforward way, Lender decides that Debtor's shares are general intangibles within the meaning of Article 9. Section 9-106 defines "general intangibles" to mean "any personal property (including things in action) other than goods, accounts, chattel paper, documents, instruments, and money." The only one of these categories under which Debtor's shares might fall is that of instruments. Section 9-105 (1)(i) defines the term "instrument" for Article 9 purposes to mean an Article 3 negotiable instrument or an Article 8 security "or any other writing which evidences a right to the payment of money and is not itself a security agreement or lease and is of a type which is in ordinary course of business transferred by delivery with any necessary indorsement or assignment." The phrase "any other writing" suggests strongly that Debtor's shares, which are not evidenced by stock certificates, fail to qualify as an Article 9 instrument. Debtor probably received a confirmation slip from his broker and a notice of registration on the books of the transfer agent of the mutual fund after his purchase, but these writings hardly qualify as instruments, given the necessary characteristics set forth in the definition as quoted. Debtor's certificateless shares are of course not negotiable instruments under Article $3,{ }^{38}$ and the Article 8 definition of a "security" is thoroughly imbued with the presupposition that a security is a writing of some sort-in the case of an equity security, a stock certificate. ${ }^{30}$

the specific paper or instrument [was] subject to a security interest." It is conceivable that, despite all this, it might nevertheless not be a holder in due course because, for example, it had notice that the note was overdue (assuming it had been called) or dishonored or that the customer had some defense against it, see $\$ 3.302(1)(c)$, or because in some way it had not acted "in good faith."

37. See note 12 supra.

38. See $\$ 3-104$ (1) (requirements for a negotiable instrument under Article 3).

39. See \$ 8-102:

(1) In this Article unless the context otherwise requires 
Suppose now that the fund, at Debtor's later request, gives Debtor a stock certificate to represent the shares that he owns, ${ }^{40}$ and Debtor turns around and pledges the certificate to Bank for a contemporaneous loan made by Bank in the ordinary course of its business. Bank, let us assume, has no knowledge of the prior security interest in favor of Lender. Since Bank thinks of stock-collaterized loans as always involving a pledge of stock certificates and the transfer of actual possession of the certificates, it does not occur to Bank that Debtor might have granted a security interest in the shares before they were evidenced by a certificate. Accordingly, Bank makes no UCC filing search in the office for the jurisdiction where Debtor is located, and does not find Lender's properly filed financing statement covering Debtor's mutual fund shares as general intangibles.

Under $\S 9-308(a),{ }^{41}$ Bank, as a purchaser for new value who acted in the ordinary course of business and had no knowledge of a prior security interest, clearly has priority "over a security interest in the... instrument which is perfected under Section 9-304 (permissive filing and temporary perfection) or under Section 9-306 (perfection as to proceeds) ...." 42 Lender's interest is, of course, not one that he would claim to have been perfected under 9-304, since there is no permissive filing as to instruments and since the temporary perfection provisions of $\S 9-304^{43}$ are here inapplicable. To the extent that it can be argued that Debtor "disposed" of his general intangible when he requested stock certificates to evidence his shares, the certificates could be regarded as "proceeds," but in this event Bank would clearly take priority over Lender's claim to the certificates as proceeds. The question then, as in the account versus note situation, is whether Debtor's shares, considered as general intangibles, ceased to exist when the stock certificate was issued to Debtor.

(a) A "security" is an instrument which

(i) is issued in bearer or registered form; and

(ii) is of a type commonly dealt in upon securities exchanges or markets or commonly recognized in any area in which it is issued or dealt in as a medium for investment; and

(iii) is either one of a class or series or by its terms is divisible into a class or series of instruments; and

(iv) evidences a share, participation or other interest in property or in an enterprise or evidences an obligation to the issuer.

(Emphasis added.)

40. The fund may be legally obligated to give the certificate when requested. See note 11 supra.

41. Quoted in note 19 supra.

42. Emphasis added.

43. See note 22 supra. 
From a conceptual point of view, the answer is not entirely clear. The residual nature of the definition of "general intangibles" in $\$$ 9-106 ${ }^{44}$ suggests, but does not logically imply, that the shares cannot be categorized as general intangibles after a certificate has been issued to their owner. It could be argued that Debtor had an interest in the corporation, or more exactly, that his general intangible had two elements-the right to get a stock certificate and the multitude of rights appurtenant to owning an equity interest in a corporation. The latter bundle of rights perdures after the issuance to him of a certificate, since the latter is only evidence of those rights. One could cite the analogy of a security interest or an ownership interest in goods; such an interest does not cease to exist merely because the goods are given to a warehouseman who issues a negotiable document of title for them. ${ }^{45}$

In fact, however, it is fairly certain, given customary practices in connection with loans for which stock is collateral and the attendant expectations that have been generated among bankers and lawyers in the financial community, that Bank would win as against Lender. Very few professional lenders would regard a stock-collateralized loan as well secured or in a priority position if the lender or his agent did not have physical possession of stock certificates. ${ }^{46}$ In order to fulfill these common expectations and permit Bank to have priority over Lender a court faced with the problem would probably decide that general intangibles cease to exist when they become represented by stock certificates.

An alternative solution might be to say that the general intangible perdures after issuance of the certificate but that Bank has priority under $\S 9-308(a)^{47}$ in the certificate and the interest it represents and that Lender maintains his status as perfected secured party with respect to the general intangible. This would mean that both Lender and Bank would have an equal claim upon the assets of the mutual fund. It is difficult to believe that the issuer, which has been entirely guiltless throughout the series of transactions, and which probably had to accede to Debtor's request for a certificate, would be subjected to such a double liability, and nothing in Article 8 demonstrates that it would be so subject. 48

44. Quoted at p. 454 supra.

45. See pp. 456-61 infra.

46. See Vagts, Pledges of Corporate Securities, in P. Coogan, W. Hogan \& D. Vagts, SECURED TRANSACTIONS UNDER THE U.C.C. $\$ 14.01$ [2], at 1503 (1973).

47. Quoted in note 19 supra. of the transfer of a security." This would not apply to the example in the text, for 
Again, $\S 9-309^{49}$ might come to the aid of the holder of the paper right if the holder qualifies-in this case, as a bona fide purchaser of the security, that is, the certificate. If Bank has such status, then it takes priority over "an earlier security interest even though perfected." We noted earlier, ${ }^{50}$ however, the ambiguity in that section. The phrase "an earlier security interest" cannot be read literally as meaning any earlier security interest in any collateral whatsoever. The phrase could reasonably be taken to mean "an earlier security interest in the same collateral," in which case it is possible to argue that the collateral in question is the Article 8 security or stock certificate, which is different from the shares themselves. The official comments to $\S 9-309$ do not negate this argument, since they refer only to competing interests in documents and instruments as such. But if we accept this view that shares and the certificates that later evidence them are not the same collateral, and that $\S 9-309$ 's reference to the bona fide certificate purchaser's priority over "an earlier security interest" means only a security interest in the same collateral, then Lender's interest would not be subordinated to Bank's by virtue of $\S 9-309$. Under this chain of reasoning, Lender could prevail as to his interest in the shares even if he had filed after the certificate was issued. ${ }^{51}$ But this goes too far: Lender's argument implies that one can always perfect a security interest in shares by making a UCC filing as to general intangibles and be protected against later pledgees of the certificates-a position which seems thoroughly contrary to common expectation and sound commercial practice.

Debtor only asked for a stock certificate, made out to himself, to represent shares he already owned and as to which he was already the registered owner; cf. $\$ 8-403$ (limits the issuer's duty of inquiry when a security is presented for registration, and which seems inapplicable for similar reasons). Lender might try to invoke $\$ 8-315(1)$ :

Any person against whom the transfer of a security [here, the pledge to Bank] is wrongful for any reason... may against anyone except a bona fide purchaser reclaim possession of the security or obtain possession of any new security evidencing all or part of the same rights or have damages.

Yet, if this subsection applies, Bank is probably an excepted bona fide purchaser; cf. $\$ \S$ 8-302, 9-309 (second sentence): a UCC filing is not notice such as automatically to defeat bona fide purchaser status. Indeed, though Comment 1 to $\$ 8-315$ suggests that our priority paradigm was not what the draftsmen had in mind, $\$ 8-315(1)$ literally seems to apply and settle the question in favor of Bank.

49. Quoted in note 20 supra.

50. See p. 453 supra.

51. Note that the Code contains nothing regarding stock certificates comparable to $\$$ 9-304(2) regarding negotiable documents, which clearly states that while a negotiable document is outstanding one perfects as to the underlying goods (that is, obtains a prior and perfected position in the abstract rights) by perfecting as to the document. 


\section{Interest in Goods versus Warehouse Receipt}

If we apply our general priority paradigm to the case of an interest in goods constituting equipment, ${ }^{52}$ which interest is later evidenced by a warehouse receipt, the result is the reverse of the likely outcome in our first two situations; here, the first secured party should prevail. (If the collateral is inventory, however, the result is less clear; the second secured party might arguably take priority.) This is not to say that the warehouse receipt is not accorded a preferred legal status. Section 9304(2) shows that possession of this sort of paper right is quite advantageous:

During the period that goods are in the possession of the issuer of a negotiable document therefor, a security interest in the goods is perfected by perfecting a security interest in the document, and any security interest in the goods otherwise perfected during such period is subject thereto.

This means that, during the period when interests in the goods are represented by the warehouse receipt, a secured party who attempts to perfect his security interest in the Debtor's goods by filing as to the goods themselves will find himself subject to the security interest of a secured party who perfects as to the warehouse receipt, even though the latter may have perfected his interest later in time. However, the obvious negative implication of the double use of the word "during" in $\$ 9-304(2)$ is that a secured party who properly perfects as to the goods themselves before they are placed in the hands of a bailee who issues a warehouse receipt will take priority over a later perfecting secured party who perfects via possession of the warehouse receipt.

Though this conclusion must be qualified in the case of goods constituting inventory of the debtor, it is otherwise supported by the line of analysis which starts from $\S 9-309 .{ }^{53}$ Section $9-309$, as in the two situations previously discussed, seems to argue for the holder of the paper right:

Nothing in this Article limits the rights of ... a holder to whom a negotiable document of title has been duly negotiated ... and such

\section{Section 9-109 states:}

Goods are...

(2) "equipment" if they are used or bought for use primarily in business (including farming or a profession) or by a debtor who is a non-profit organization or a governmental subdivision or agency or if the goods are not included in the definitions of inventory, farm products or consumer goods....

53. Quoted in note 20 supra. Unlike the account versus note and share versus certificate situations, a $\$$ 9-308(a) line of analysis not here possible. Section 9.308(a) deals only with purchase of "instruments" and "chattel paper"; warehouse receipts are "documents." 
holders...take priority over an earlier security interest even though perfected. Filing under this Article does not constitute notice of the security interest to such holders or purchasers.

As suggested above, the language of this provision is ambiguous: "An earlier security interest" might conceivably refer to the perfected security interest of a secured party who perfected his interest before the goods were given to a bailee that issued a negotiable document of title concerning them, or it might refer only to an earlier security interest in the document. In the two previously discussed situations, one could only note the ambiguity and make more or less convincing arguments about its proper resolution (that the second secured party-the paper right holder-should prevail). This resolution rested partly on the desire to harmonize $\S 9-309$ with the more demonstrable result under $\S$ 9-308(a), and might seem to imply that when $\$ 9-309$ speaks of priority over "an earlier security interest" it must mean priority over "an carlier security interest in the documents or instruments or in the abstract interests which they later came to evidence." In other words, one is tempted to see an implication that the narrow interpretation of the "same collateral," according to which correlative abstract rights and paper rights are separate and distinct, must be wrong. However, this reading of $\$ 9-309$ cannot be universalized, for the narrow interpretation of "same collateral" is supported by the UCC's resolution of the warehouse receipt situation. In this instance, $\$ 9-309$ does not have to be read as giving priority to the later secured party over the earlier perfecting holder of the abstract right, because a more specific UCC provision, $\S 7-503(1)$, must be taken into account. That section states in pertinent part:

A document of title [such as a warehouse receipt issued to a debtor and then duly negotiated by him to a second secured party unaware of a pre-bailment security interest in the covered goods] confers no right in goods against a person who before issuance of the document had... a perfected security interest in them and who neither

(a) delivered or entrusted them ... to the bailor [the debtor] ... with actual or apparent authority to ship, store or sell ... or with power of disposition under this Act (Sections 2-403 and 9-307) or other statute or rule of law; nor

(b) acquiesced in the procurement by the bailor or his nominee of any document of title.

Under $\$ 7-503(1)$, then, a secured party who perfects a nonpossessory security interest in a debtor's goods is protected from the contingency 
of a fraudulently procured document with respect to collateral which is equipment. He can simply refuse to acquiesce in the issuance of a document. If, as assumed by our basic priority paradigm, he does not even know of its issuance, and later objects to it, he cannot have acquiesced and will prevail against the secured party who took possession of the paper right. ${ }^{54}$

According to Professor Gilmore, ${ }^{55}$ however, there is nothing the first secured party can do if the collateral is inventory held by the debtor for sale; the debtor does have "power of disposition under this Act" with respect to the inventory. His security interest is clearly defeated when debtor negotiates the document to a buyer in ordinary course of business, and an argument-wrong, I believe-can be made that it is defeated when debtor negotiates it to a second secured party who takes the paper right as security for a loan. ${ }^{56}$

It is therefore clear that the phrase "an earlier security interest" in $\S 9-309$ does not mean the same thing in all of the cases affected by that

54. It perhaps requires some explanation to understand in adequate detail the application of $\$ 7.503(1)$. Suppose that Debtor grants a security interest in goods to Bank, which promptly perfects by filing on January 1. On February 2, Debtor wrongfully bails the goods with a warehouseman who issues a negotiable warehouse receipt for them. On February 4, Debtor "duly negotiates" the warehouse receipt as prescribed in $\$ 7-501(4)$ to Finance Company, which takes possession of the receipt as security for a contemporaneous loan to Debtor.

Section 7-503(1) states in effect that the warehouse receipt, whether in the hands of Debtor or in the hands of Finance Company, confers no right in the goods superior to Bank's security interest if Bank did not do certain things, such as "entrusting" the goods to Debtor (the "bailor") with power of disposition under $\$ \$ 2-403$ and 9-307 or "acquiescing" in Debtor's procurement of the warehouse receipt. The apparent negative implication is that if Bank did do either of these things, Finance Company's security interest would have priority over Bank's earlier perfected security interest.

It is therefore crucial to determine whether Bank did any of the things mentioned in subsections (a) and (b) of $\$ 7-503(1)$. I assume throughout that Bank did not acquiesce in Debtor's procurement of the warehouse receipt, so that Bank will not be subordinated to Finance Company on this score. The various activities mentioned in subsection (a) all seem inapplicable to anything Bank did, with the possible exception of an "entrusting" of the goods to Debtor "with power of disposition under this Act (Sections 2-403 and 9-307)." "Entrusting" is defined in $\$ 2-403(3)$ to include inter alia "any acquiescence in retention of possession...." It appears clear, then, that in the defined sense Bank did "entrust" to Debtor the goods serving as collateral for its loan to Debtor, since it did not insist on taking possession of the collateral. The next question is whether the goods were entrusted to Debtor "with power of disposition under this Act (Sections 2-403 and 9-307)" and, as a reading of the cited sections indicates, this depends in essence on whether the goods were "inventory" (\$9-109(4)) to Debtor.

Thus, if the goods in question were not inventory but equipment (\$ 9-109(2)), Bank will not have done any of the things specified in subsections (a) and (b) of $\$ 7.503(1)$ and it will have priority over Finance Company, the holder of the paper right.

55. 2 G. Gilmore, Security Interests in Personal Property 166 (1965).

56. The situation when the goods are inventory is difficult because of the peculiar wording of $\$ 7-503(1)$. To revert to the example described in note 54 infra, Finance Company will obviously argue that Debtor had power of disposition over the inventory, since under $\$ \S 2-403(2)$ and 9-307(1) it could have transferred good title superior to Bank's interest to a "buyer in the ordinary course of business," and so Finance Company's security interest in the document should have priority over Bank's security interest in 
section. It cannot be argued that the phrase per se implies that a favored secured party taking possession of a paper right will have priority over an earlier perfected security interest in the underlying abstract right before the latter became "paperized." This conclusion holds in the account versus note and shares versus certificate situations, but not in the interest in goods versus warehouse receipt situation-at least when the goods are equipment-and in each case the result flows not from the wording of $\S 9-309$ but from other Code provisions and policies.

\section{Interest in Goods versus Chattel Paper}

Suppose that Seller sells goods to Buyer on a conditional sale basis, and gets Buyer to sign a security agreement which simply recites that Buyer is granting a security interest in the specified goods in favor of Seller "for value received." Assume that the quoted reference is vague enough so that the paper copy of the security agreement which is obtained by Seller does not constitute "a writing or writings which evidence both a monetary obligation and a security interest in or lease of specific goods...," and is therefore not "chattel paper" within the meaning of $\S 9-105(\mathrm{l})(\mathrm{b}) .{ }^{57}$ Seller then assigns his rights against Buyer to Bank. Since Seller has perfected its security interest against Buyer by a proper filing of a financing statement, on which is noted the assignment to Bank, Bank realizes that under $\S 9-302(2)^{58}$ it need do nothing further in order to keep itself perfected as against creditors of and transferees from the original debtor, Buyer. But, being cautiously concerned with the possibility of Seller's bankruptcy, Bank pays particular attention to comment 7 to $\S 9-302(2)$ in the 1972 official text of the UCG:

the goods. Bank will reply that in fact Debtor attempted to dispose of the goods, not to a buyer in the ordinary course of business, but to Finance Company, which is a "purchaser" (see $\$ \S 1-201(32)$, (33)) but not a "buyer in ordinary course of business" (see $\$ 1-201(9)$ ) within the meaning of the UCC definitions. It will contend that $\$ 7-503(1)$ did not mean to give Finance Company a priority over Bank's own earlier perfected security interest simply because Debtor could have defeated Bank's rights in the goods by transferring the warehouse receipt to a buyer in ordinary course. The only negative inference properly to be drawn from the subsection, it will say, is that it is helpless against such buyers. Since I believe that the policy reasons developed in the next section, see pp. 467-68 infra, to support priority for the first secured party who takes an interest in equipment apply with equal or greater force to a first secured party taking an interest in inventory, $I$ think it desirable that Bank's arguments should be accepted and those of Finance company rejected.

57. See note 8 supra (text of $\$ 9-105(1)(b)$ ) (emphasis added).

58. If a secured party assigns a perfected security interest, no filing under this Article is required in order to continue the perfected status of the security interest ${ }^{\text {. }}$ against creditors of and transferees from the original debtor. 
Buyer buys goods from Seller who obtains a security interest in them which he perfects. Seller assigns the perfected security interest to $X$. . . If . . . the assignment from Seller to $X$ was itself intended for security (or was a sale of accounts or chattel paper), $X$ must take whatever steps may be required for protection in order to be protected against Seller's transferees and creditors.

The comment seems to say only that if the assignment to Bank was intended as security, or was a sale of accounts or chattel paper, a perfecting action against Seller is necessary. This seems to leave open the possibility that an outright assignment without recourse (that is, a "sale") of all of Seller's rights (including its security) against Buyer would not require Bank to take any perfecting action. However, Bank is concerned that the transaction, even if so structured as an outright sale, would at least be analyzable as including a sale of Buyer's monetary obligation, which obligation could be classified as an account, and so Bank decides to be as safe as possible by making a proper UCC filing against Seller as debtor, with itself listed as secured party.

Suppose now that Seller imposes upon Buyer to make a "clerical clarification" of the following form: Buyer types on Seller's executed copy of the security agreement the words, "The security interest created by this security agreement is intended to secure Buyer's monetary obligation, created by a loan from Seller to Buyer on December 10,1974 , to pay $\$ 9,000$ to Seller, which obligation Buyer hereby acknowledges and ratifies." The insert is dated and signed by Buyer. Seller then takes the security agreement and delivers it to Finance Company as security for a contemporaneous loan by the latter to Seller. Seller later goes into bankruptcy, and the issue is whether Finance Company or Bank has priority in Seller's right against Buyer.

The analytical problem will seem quite familiar by this time. Under $\S 9-308(a),{ }^{60}$ Finance Company is literally given priority over other security interests in the chattel paper, but nothing explicit is said about priority over an earlier perfected abstract security interest which later became embodied in or evidenced by the specific chattel paper in question. Bank does not claim perfection by temporary or permissive filing, nor does it claim an interest in the chattel paper proceeds-or if it does, it is bound to lose. Bank is rather claiming that it is assignee of a secured party and that it has a properly perfected security interest in Buyer's goods themselves, or at least in the entire bundle of Seller's rights against Buyer.

59. See note 9 supra (UCC definition of an "account").

60. Quoted in note 19 supra. 
As in the case of the loan secured by stock collateral, and unlike the case of the secured financing based first on an account and then on a note, ${ }^{01}$ the definition of the relevant paper right (here, chattel paper) does not logically imply the view that the correlative but prior abstract right was extinguished when the paper right began to evidence it, and therefore a strict, literal reading of $\S 9-308$ (a) does not tell us who prevails as between Bank and Finance Company. But unlike the case of the loan based on stock collateral, where commercial practice dictated that priority be given the holder of the paper right, there does not appear to be so strong a sense of customary practices and expectations which could be invoked to lead to a solution considered right by nearly everyone.

If, then, the abstract right continues to exist and § 9-308(a) therefore does not answer the priority problem, resort must be had to the general priority sections, $\S 9-301$ and $\S 9-312$. Section 9-301 deals in pertinent part with conflicts between perfected secured parties and unperfected secured parties both having interests in the same collateral. ${ }^{62}$ This section could be relevant if one were to say that "paperizing" a right creates new and distinct collateral, giving Bank a security interest in one batch of collateral, the goods as they are in the hands of Buyer, and Finance Company a perfected security interest in another item of collateral, Seller's chattel paper. Finance Company has priority as to its security interest in the chattel paper, since Bank claims an interest in the chattel paper, if it claims one at all, as proceeds and is thus subordinate to Finance Company by virtue of $\S 9-308(a)$. But, so the argument goes, this does Finance Company very little good in this situation. Bank has priority under $\S 9-301$ as to its security interest in the goods themselves since it is perfected as to the goods and Finance Company is not perfected as to the goods as such.

The problem with this reasoning is that Finance Company's security interest in the chattel paper has value only because it represents a

61. The warehouse receipt situation is not mentioned here because, as stated in note 53 supra, $\$$ 9-308 does not apply to "documents" like warehouse receipts.

62. Except as otherwise provided in subsection (2), an unperfected security interest is subordinate to the rights of

(a) persons entitled to priority under Section 9-312;

(b) a person who becomes a lien creditor before the security interest is perfected;

(c) in the case of goods, instruments, documents, and chattel paper, a person who is not a secured party and who is a transferee in bulk or other buyer not in ordinary course of business or is a buyer of farm products in ordinary course of business, to the extent that he gives value and receives delivery of the collateral without knowledge of the security interest and before it is perfected;

(d) in the case of accounts and general intangibles, a person who is not a secured party and who is a transferee to the extent that he gives value without knowledge of the security interest and before it is perfected. 
security interest in the goods themselves. It is therefore practically necessary for us to say that, as in the case of the warehouse receipt, one perfects as to the goods $b y$ perfecting as to the chattel paper after the latter has been created. This is so even though Article 9 does not state the proposition in so many words.

However, none of this really helps Finance Company. Granted that it has a perfected security interest in the goods by virtue of its perfected security interest in the chattel paper, how does this indirect security interest in the goods stack up against Bank's earlier, perfected, direct security interest in the goods? Since no other UCC provision seems to settle the dispute, reference must be had to the residual priority rule of $\S 9-312(5) .{ }^{63}$ That section does not distinguish between direct and indirect security interests in goods, so there is no reason to believe that it is not applicable. Under its rule, Bank, being first in time to perfect, clearly prevails over Finance Company. ${ }^{64}$

\section{E. Summary}

The results of our inquiry may be summarized. In the case of the account later converted to a note, one can feel fairly certain that the innocent later perfecting secured party who takes possession of the note will prevail over the earlier perfecting and equally innocent secured party who filed as to the account. In the case of the certificateless shares that later became evidenced by a stock certificate, a strict, close reading of the UCC's provisions does not logically imply the proper solution, but general expectations in the financial community lead one to predict that the later perfecting party who took possession of the stock certificate would prevail over the equally innocent and earlier perfecting secured party who simply made a UCC filing as to

63. In all cases not governed by other rules stated in this section (including cases of purchase money security interests which do not qualify for the special priorities set forth in subsections (3) and (4) of this section), priority between conflicting security interests in the same collateral shall be determined according to the following rules:

(a) Conflicting security interests rank according to priority in time of filing or perfection. Priority dates from the time a filing is first made covering the collateral or the time the security interest is first perfected, whichever is earlier, provided that there is no period thereafter when there is neither filing nor perfection.

(b) So long as conflicting security interests are unperfected, the first to attach has priority.

Note that the 1962 text, though differently stated, would have the same result because "priority between conflicting security interests in the same collateral shall be determined as follows: ... (b) in the order of perfection unless both were perfected by filing, regard. less of which security interest attached first..." $\$ 9-312(5)$ (1962 Official Text).

64 . Note that $\$ 9-309$ does not apply at all to chattel paper, though it did enter into the discussion of each of the other three exemplifications of the priority paradigm. 
the certificateless shares considered as general intangibles. In the case of the equipment turned over to a warehouse, the later perfecting secured party who takes possession of the warehouse receipt loses to the equally innocent earlier perfecting secured party who filed during the pre-bailment period as to the equipment itself. If the bailed goods are inventory the outcome is arguably, though perhaps regrettably, ${ }^{65}$ the opposite. Finally, in the case of the abstract security interest in goods which later became evidenced by chattel paper, neither the logic of the UCC itself nor any easily recognizable general expectations give us firm assurance that we have the answer. A rather policy indifferent analysis of the UCC provisions supports the argument that the earlier perfecting secured party who was assigned the abstract security interest should prevail over the later perfecting secured party who took possession of the chattel paper, but, given the latitude possible in interpreting $\S 9-308(a)$, the conclusion is hardly inevitable.

\section{Evaluation of the Four Patterns of Priority}

The preceding analysis treated the UCC as a given, self-contained system of formal principles that can be logically manipulated to produce answers to specific problems. The present section explores policy considerations that help one to understand, justify, and criticize the results of the four priority problems that would apparently be reached under the current UCC.

The following discussion assumes that it is desirable for a legal system to reduce as much as possible various costs which impede the flow of commerce. For convenience, I will distinguish kinds of costs. The irritations, inefficiencies, and injustices that result from frauds I will refer to as "fraud costs." Costs created by the lack, most apparent in purely oral agreements, of a fixed ${ }^{66}$ and uniquely embodied or located verbal formulation of rights I will describe as "unfixity costs."

65. See note 56 supra.

66. A formulation may be "fixed" in memory even in a system of totally abstract rights. However, since memory is finite and may shift over time, and since memories may differ among persons, the society which rests on the fixation of rights in memory faces grave difficulties when commercial life evolves to a point which demands that numerous and complicated transactions take place in a specdy and reliable way. See p. 474 infra.

67. I apologize for the barbaric phrase, though I would point out that "unfixity" is not a neologism. See 2 The Compact Edirion of THE OXford ENGLish Dictionary 3504 (1971). An apparent alternative, "uncertainty costs," has connotations that I wish to avoid: Statisticians, financial theorists, and economists will think rather of uncertainty about future states of affairs. "Ambiguity costs" would simply be insufficient; for cxample, though one consequence of the nonfixation of legal rights may well be that understandings of rights are ambiguous, another may be that the parties' understandings of their rights shift perceptibly over time-a process which does not necessarily imply that the original understandings of the rights were unclear. 
Examples of unfixity costs are the costs of uncertainty, confusion, disagreement, shifts in understanding and memory, and a general tendency toward neglect of precision and detail..68

Let us first reexamine the two priority problems which have the clearest solutions. In the account versus note example, priority was awarded to the holder of the paper right, even though he came later in time; in the interest in goods versus warehouse receipt example involving collateral that was equipment, priority was given to the first secured party even though he took an abstract right. Why do these two solutions differ?

There is little difference between the two situations in the matter of reducing unfixity costs. In both situations, both secured parties took roughly equivalent steps to reduce unfixity costs: the first secured party satisfied the Statute of Frauds in each case, and the second secured party took possession of a fairly standardized paper right. ${ }^{69}$

A different perspective on unfixity costs is suggested, however, if one attends to whether the various secured parties took interests in a tangible or intangible right. Perhaps because of widespread psychological preferences, abstract rights in intangibles call for and receive a more definitive and legally favored fixation in paper form than do abstract rights in tangibles. Put another way, people generally seem to want paper rights in intangibles more than they want paper rights in tangibles, and this may lead them to insist that paper rights in intangibles, such as notes, embody or be identified with the correlative abstract right, to such an extent that the symbol becomes psychological-

68. A few comments on the distinction between fraud costs and unfixity costs may prevent some misunderstandings. First, I recognize that the two categories overlap. One of the costs of unfixity may be the facilitation of fraud: the Statute of Frauds is a perfect example of belief that unfixity furthers fraud. However, fraud is facilitated by many things other than unfixity, e.g., by child-rearing practices that reward cunning and deviousness; fraud may be reduced by means that do not involve reducing unfixity. Moreover, fraud is such a predominant theme in commercial law that I have thought it best to treat fraud costs as a separate category. Second, I speak of fraud "costs" and unfixity "costs" because the term "costs" connotes measurability in principle and suggests that there are efficient and inefficient ways to reduce fraud and unfixity. A legal system should not simply minimize fraud, it should do so cheaply; what is wanted is a reduction in net fraud costs. Third, as will become apparent in the textual discussion, I do not mean to imply that fraud costs and unfixity costs can be meaningfully monetized. I doubt that all consequences of fraud, or of the nonfixation of legal rights, which can plausibly be regarded as unfortunate, unpleasant, disruptivc, dysfunctional, or the like, can, given the present structure and functioning of our economy, be accurately expressed in dollars and cents. In particular, the basically dysfunctional nature of the nonfixation of legal rights is better grasped from a psychological than an economic standpoint. Though psychological needs unsatisfied by abstract ("unfixed") rights may have gradually called forth commercial practices to satisfy those needs, it would be difficult to detect a reflection of these needs in prices.

69. Note that the Statute of Frauds is now incorporated in the UCC, see, e.g., $\$ 9$ 203(1)(a), while the UCC also sets forth the basic scheme of paper rights now used in commercial practice. See, e.g., Article 3. 
ly equivalent to the thing symbolized. ${ }^{70}$ If so, it becomes natural to expect that the later perfecting secured party will win in the situations involving intangible rights represented by the note, while the earlier perfecting secured party will win in the situations involving goods as to which interests were later evidenced by a warehouse receipt. But apart from the rather ethereal psychological benefits just hypothesized, it is difficult to perceive how the policy of reducing unfixity costs indicates that there ought to be such a difference in treatment between holders of instruments, on the one hand, and holders of documents on the other. If Article 9 were intended to make such a clear-cut dichotomy, the mixed-up treatment of instruments, documents, and chattel paper in $\$ \S 9-308$ (a) and 9-309 certainly obscures that intention.

It is more illuminating to consider the relative abilities of the first secured parties to reduce fraud costs cheaply by protecting themselves. In the warehouse receipt case, it would hardly be fair to tell the first secured party that he should write all warehouses that might conceivably deal with his debtor and tell them not to issue a warehouse receipt to the debtor, or alternatively, to note the secured party's interest on any receipts that were to be issued. Such a task would be indeterminate, and would be especially unfair if, as has been supposed, the secured party had not the slightest idea that his debtor would bail the goods or if the relevant security agreement prohibited such bailment.

By contrast, it is more feasible for a bank entering into a general accounts receivable financing agreement with a dealer to write all the account debtors and tell them not to give the debtor a note evidencing their account obligations. Depending upon the kind of accounts receivable arrangement in question, this task of notification might be extremely burdensome and impractical, but at least the number of debtors would be limited and knowable, and notification might have some practical, if not legal, advantage. It seems fair in this situation to give the bank the problem of trading off between the expenses of notification and the risks attendant upon failure to notify the members of this defined class of account debtors. ${ }^{71}$

70. See Vagts, supra note 46, § 14.01[2], at 1503 .

71. It should be observed that in the account versus note situation, notification or lack of it may have roughly the same consequences as in the warehouse receipt situation, with respect to the first secured party's prospects for obtaining payment from the notemakers or the warehouseman. Without notification to the warehouseman, the first secured party cannot force the warehouseman who acts in good faith to make payment to it on account of a delivery of goods to the rival secured party, see $\$ 7-404$; without properly worded notification to the account debtors, the first secured party cannot later argue that those account debtors should have to pay it the amount of the former accounts if they have made payment of the notes to the second secured party. 
Furthermore, in the existing world of secured financing, arrangements sort themselves out in a way that reduces the severity of the problem faced by the bank. Banks and finance companies entering into accounts receivable financing arrangements with wholesalers and retailers often do not require hypothecated accounts to be evidenced by notes for precisely the same reasons that a later, wholesale, and fraudulent conversion of the accounts to notes would be difficult to execute and conceal: the accounts are numerous, the amounts owing on them are frequently being added to and paid down, account debtors are added and dropped, and the account debtors' geographical location, attitudes, and willingness to cooperate may be diverse. In cases where fraud is more feasible-as where a bank loans money to a corporate parent partly on the security of a number of intercorporate debts owed by subsidiaries to the parent-it is less burdensome to demand that the bank, if it wants the greatest degree of legal protection, make sure that promissory notes are given to evidence the debt and are pledged to it.

The solutions of the two priority problems are confirmed when one turns to a consideration of what the second secured parties can do in each case to prevent fraud upon themselves. The warehouse receipt case is easy. The second secured party could, without much cost or expense to itself, make a UCC filing search, discover the prior security interest in the bailed equipment, and thus prevent a fraud upon itself. Thus the solution to the problem, that the comparatively defenseless first secured party should have priority, is just. ${ }^{72}$

In the case of the accounts later converted to notes, the reasoning is somewhat more complex. It is true that putting a potential second secured party, who would like to take possession of notes held by his debtor, to the task of making a filing search for security interests in accounts would not itself impose a great cost on him. However, the information discovered by the filing search is likely to be inadequate. ${ }^{73}$

72. One might think that priority for the first secured party is also supported in terms of a general "first in time, first in right" principle, traces of which are embodied in the UCC (see, e.g., $\$ 9-312(5)$ ). As explained at p. 475 infra, I believe that this principle per se has minimal independent significance as a justification for a particular resolution of a priority dispute. In a particular manifestation, e.g., "first to file, first in right," the principle may have significant justificatory force because it states a rule that arguably tends to reduce fraud costs, or that tends to achieve other valuable objectives.

73. A related but minor point may be made. The second secured party in the account versus note situation would only be searching the filing records to obtain information that might prevent the very particular and not terribly common form of fraud involving conversion of accounts to notes, since one cannot perfect security interests in instruments per se by filing. In the warehouse receipt situation, the second secured party might have been making a filing search for other purposes: There might be a prior security interest in the document which he would as a practical matter like to know about, even though his perfection by taking possession of the document would create a prior interest. 
In the case of a debtor with many account debtors, the financing statement filed by the first secured party typically would state simply that it covers all past and future accounts receivable of the debtor. Even if the second secured party pursues the matter and obtains a copy of the original security agreement, he will likely find only the same description. To satisfy himself, he will therefore have to contact all the makers of the notes being proffered to him as collateral, and ask for information about whether the notes were given to evidence previously existing accounts which arose during a period covered by the financing statement of the first secured party and which fit within its terms. This information might or might not be supplied by the makers of the notes, and might or might not require independent verification.

By contrast, the worried first secured party could have protected himself by simply notifying the account debtor of the debtor's assignment of the accounts to himself; he need not have gone through the expense and uncertainty of prodding the account debtors into making affirmative responses to his requests for information, and then evaluating those responses, as the second secured party would. The entire process of inquiry and verification by the second secured party would be costly and, more importantly, in the great number of cases in which proposed debtors are not fraudulent it would yield no information that would change the second secured party's proposed course of action. Considering these burdens, the policy of shifting the risk of a conversion of accounts into notes to the first secured party and giving priority to the second secured party seems wise. The contrasting results in the account versus note and the interest in goods versus warehouse receipt cases set out in the first section of this article are thus defensible. ${ }^{74}$

The result in the certificateless share versus stock certificate example, that the secured party taking the paper right prevails, may be considered next. The result, as suggested before, may be justified by reference to general expectations: Anyone having any experience with loans secured by stock collateral would have little sympathy for the plight of a secured lender who is so inexpert as not to require physical delivery of the certificates themselves, either to himself or to some trusted agent or third party. This may reflect the psychological preference for reducing unfixity costs by the use of paper rights when intangibles like shares are at issue.

74. Another explanation, if not a justification, of the different results in the two cases may be that warehouse receipts have simply not yet risen to the preferred legal status that the more common promissory note has. 
Fraud costs could likewise be most easily reduced by the first secured party in view of current practices; few, if any, secured parties file as to general intangibles in the case of a stock-collateralized loan, and few would think to check for such filings before making a loan. If the proposed debtor holds certificateless shares, it is still an easy matter to require him to ask the issuing company for a certificate which could then be pledged. ${ }^{75}$ Here again, the result derived in the earlier discussion of the priority paradigm seems correct.

In the example involving an interest in goods versus chattel paper, the first perfecting party was given priority under $\S 9-312(5)$, the residual priority section. ${ }^{76}$ This solution is the most difficult of the four to evaluate, perhaps because chattel paper does not have quite the same legal dignity as negotiable instruments and because the particular example posed is less common. The UCC's definition of "chattel paper"77 is so extensive as to include almost any written security agreement that would arise in normal practice, so that it will be unusual to find a situation in which an abstract security interest is later converted into chattel paper and then conveyed to a different secured party. Nevertheless, the example is of great theoretical interest.

To explore its implications, we begin by considering unfixity costs. By hypothesis, the chattel paper contains more information in paperized form than did the security agreement which merely evidenced the abstract right and satisfied the Statute of Frauds, since the latter gave

75. However, the current received learning will turn out to be an inappropriate bias as the stock market becomes more and more based on devices designed to eliminate certificates. It is somewhat paradoxical that, in recent extensive discussions of the certificateless society, there is little mention of the secured loan problems that will be created: most of the current discussion is focused on the simple situation of buying and selling. See, e.g., Potter \& McLean, Introduction to Book Entry Transfer of Securities, 28 Bus. LAw. 209 (1972); S. Robins, W. Werner, C. Johnson \& $A$. Greenwald, Paper Crisis in the Securities Industry-Is the Stock Certificate Necessary?, 1969 (report prepared by Lybrand, Ross Bros., \& Montgomery). But see Coogan, The New UCC Article 9, 86 HARv. L. RLv. 558-63 (1973) (discussion of security problems associated with the certificateless society).

In any event, in a certificateless society there would be no reason to give priority to a later perfecting secured party who managed to induce his debtor to convert his certificateless rights into paper rights. It is equally clear that the present scheme of Article 9 could not be made workable for a certificateless society merely by making it clear that such a secured party loses to a secured party who earlier filed as to the shares considered as "general intangibles." A filing as to general intangibles is made in a location determined by the residence of the debtor. This is perfectly absurd in the case of interests in corporations, all of which either have a registrar and a transfer agent within the corporation itself or outside of it. The most natural focus for recording all interests of every sort in shares in a corporation is on the same records which are used to determine voting and dividend rights, namely, records kept by the transfer agent. Either Article 8 or Article 9, or both, would have to be amended to provide for a more rational system.

In the meantime, notifying the issuing corporation of a security interest will only serve, if anything, as a way of speeding up an anticipated perfection by possession; $c f$. Heinecke Instruments Co. v. Block, 14 UCC REP. SERv. 167 (D. Ore. 1974).

76. Quoted in note 63 supra.

77. Quoted in note 8 supra. 
no information about the monetary obligation being secured. The reduction of unfixity costs achieved by chattel paper thus suggests giving priority to the second secured party.

This conclusion is not contradicted by an examination of who can most cheaply reduce fraud costs. Since our particular situation (a most unusual one) involves highly complex considerations of fraud costs, it will be helpful first to examine a variant priority problem that is clearly settled by $\S 9-308$ (a). Suppose that no abstract right was involved and that the debtor gave the first secured party a security interest in (though not possession of) chattel paper. If the first secured party files, fraud on the second secured party will in fact be prevented if the second secured party makes a filing search. But he will probably not make such a search, because if he takes possession of the chattel paper, he will prevail under $\$ 9-308$ (a) over the first secured party unless he has knowledge of the latter's security interest. Indeed, since knowledge in the Code means only actual knowledge and does not include the constructive notice created by a filing, the second secured party has a positive incentive not to make a filing search. A fraudulent second transfer is thus quite possible, and under $\$ 9-308(a)$, which gives the second party priority, the first secured party will clearly suffer the consequences.

Is this rule sound? If the rule were the opposite, according priority to the first secured party to file, the second secured party would be motivated to make a filing search, thus nipping fraud in the bud. Moreover, this opposite rule would make it pointless for the debtor to attempt fraud-as he could under the $\$ 9-308$ (a) rule-by passing off a copy of the chattel paper as the original to a second secured party; under a first-to-file rule, the second secured party would not rely on getting possession of chattel paper but would check the filing records and thus discover what was about to happen.

But the first secured party has his own means of preventing fraud. $\mathrm{He}$ can always protect himself by filing and taking possession, without incurring great additional expense. The only possibility of fraud then left open would be the debtor's passing off a copy of the chattel paper to a second secured party as the original-which might be thought an acceptable risk. Even if the type of financing involved is such that dealers are customarily left in possession of the chattel paper-for example, because the dealer is a better bill collector than the financer and having the paper facilitates his collection efforts-the first secured party can take steps to assure that each original copy of a piece of chattel paper is stamped with a notice that it has been transferred as 
security. If this plan is implemented, it will give actual knowledge to the potential second secured party and will thus reduce the possibility of fraud. In summary, although according priority to the second secured party under $\S 9-308$ (a) is at first blush surprising in light of the policy of reducing fraud costs, it is not obviously or drastically wrong, because of the ease with which the first secured party can take possession of the chattel paper.

In this light, the priority problem involving the abstract security interest later converted into chattel paper becomes more tractable. In the previous example, a first secured party took as collateral not a mere abstract right but chattel paper; yet he merely filed as to it. He was subordinated to a later secured party who took possession of the chattel paper without making a filing search. A fortiori a second secured party should also prevail over a first secured party who merely files as to the unconverted abstract right.

This outcome under $\S 9-308(a)$ is, admittedly, ambiguous with respect to fraud costs. It can perhaps be best understood as an attempt to encourage paperization of rights and a consequent reduction of unfixity costs by penalizing the possessor of the merely abstract right. ${ }^{78}$ The reduction of unfixity costs, with the priority this entails for the second secured party in the situation, is thus the determinative factor in the example involving an interest in goods versus chattel paper; it leads one to conclude, albeit hesitantly, that the first party priority deduced from $\S 9-312(5)$ in the previous section is incorrect. ${ }^{70}$

78. One should bear in mind that the first secured party's position is not like that of the first secured party in the warehouse receipt situation, the other situation in which tangible goods are at issue. The latter has no idea as to what warehouseman the goods might be turned over by the debtor in exchange for a paper right, nor is it economically sensible for anyone to insist that the possibilities be fixed by having the debtor bail the goods to a warehouseman for the mere purpose of preventing a fraudulent future bailment. In the chattel paper situation, by contrast, the first secured party can easily know the specific identity of the obligor, the ultimate creator of the security interest being assigned, and it is not unfeasible or inconvenient to insist that the right be made into chattel paper, and then possessed or stamped by the secured party. This simply involves having the ultimate obligor sign a slightly different-and, indeed, more common-type of form.

79. This conclusion obviously is based on my feeling that a residual decisional rule, $\$$ 9-312(5), should not carry the day if other considerations point toward priority for the second secured party. There are two other factors which might be of some relevance in evaluating this situation. First, a conceivable reason for awarding priority to the first party would be that the result would create a kind of parity with the result of the warehouse receipt situation, which from a psychological point of view is analogous because both involve rights in tangible goods. To the extent that analogous situations receive similar legal treatment, the relevant legal rules will become more widely known and protective action oriented around their existence is more likely to occur. This argument seems, however, to be so general as to deserve only slightly more weight than a primarily arbitrary decisional rule like the first-in-time principle of $\$ 9.312(5)$.

Second, if one considers the parties from the point of view of fairness, that is, in light of the relative strength and validity of their expectations, the scales seem evenly balanced. Since the kind of situation I hypothesize is uncommon, it is reasonable to suppose that 
III. General Considerations: The Evolution of the Tendency to Suppress Abstraction

Having struggled through the statutory labyrinth and walked the dusty sidewalks of policy, we may be permitted a romp through the woods of general theory.

The most interesting thing about the priority paradigm is not the intrinsic obscurity of the UCC solutions to the four problems or the policies behind the different patterns, but the striking way in which the different patterns raise questions about the general framework of ideas in Article 9. In this section, some of the policies just used in evaluating the UCC's patterns of priority will themselves be considered in a more systematic account of the various theoretical principles involved. The principal objective is not to shed any more light on the four priority problems or to make their justification or criticism more solid. It is simply to obtain a better theoretical understanding of the differing principles in Article 9. Such an understanding, besides hinting at a variety of sociological hypotheses, may make us more critical in detecting and keeping in perspective biases present in the Code itself as well as in legal arguments about its proper interpretation.

As is evident from the four patterns of priority discussed above, the Code does not always provide that the secured party who files, even if he files before anyone else perfects, should prevail. Instead, the law often displays a strong preference in these and other situations for paper rights as against earlier established, correlative, abstract rights.

In order to understand why this is so, let us imagine first a society in which all rights are abstract. Though individual human beings have definite and legally recognizable rights to the use and disposition of various pieces of property, none of the rights is evidenced by a piece of paper or in any public or private recording or filing system. ${ }^{80}$ In such a society, consider the class of rights that concern property (or complexly and indirectly defined pools of property) not in the physical

the first secured party would not expect the subsequent conversion of the abstract right into a paper right and its fraudulent transfer to another party. Correlatively, however, there need be nothing in the paper right or in the context to lead the second secured party to suspect that it was taking possession of the converted form of an already transferred abstract right.

80. There could be various degrees of departure from this extreme. For present purposes, a society"s rights could be said to become "less" abstract by virtue of any one or more of the following: an increase in the relative frequency of rights evidenced by pieces of paper (or in some other permanent medium); an increase in the extent to which certain rights are regarded as identified with particular pieces of paper, for which copies are no substitute; and an increase in the number or kind of cases in which access to or the location of such single paper rights is legally controlled. 
possession of the individuals having the rights. ${ }^{81}$ A potential transferee may not trust the transferor as a source of evidence: The transferor may be lying; he may have the right but be confused as to the various subtle details of its nature; he may have a faulty memory; he may have told a different story to someone else; and so forth. Perhaps most importantly, even if he tries earnestly to describe his right accurately and in detail, his mode of description may vary from one occasion to the next. This shifting and variable characterization of the right is important, for in many unforeseen conflict situations a fixed verbal formula interpreted principally in accordance with the customary legal or ordinary meanings given to its component words may be the only, or at least the best, way to resolve the conflict in a neutral and equitable manner.

The fear that the potential transferor may be lying can be mitigated to some extent by getting other individuals to vouch for his ownership of the right. But this procedure is inconvenient. The voucher must both be in a position to know of the transferor's right and be known to or accepted by the transferee as a credible informant. Given a certain common level of need for such vouching, the possible participants in many commercial transactions would be restricted to those persons who have a nexus of personal connections to a satisfactory voucher. Such a system would be economically inefficient, since it needlessly curtails the range of feasible exchange transactions. Moreover, even the statements of an earnest and credible voucher have the same defects as the transferor's statements: His descriptions of the right will tend not to have a fixed formulation.

For the sake of simplicity, one might categorize the various irritations and inefficiencies of a system of totally abstract rights under the two major headings that were previously introduced: "fraud costs" created by the occurrence of the fraudulent transactions which are permitted by this system, and "unfixity costs" created by the lack of a fixed and uniquely embodied or located verbal formulation of the rights.

Because of the inadequacies and costs of the abstract holding of rights, there will naturally be pressures in a legal system to reduce or eliminate this kind of abstraction. A variety of doctrines and devices for facilitating and encouraging the reduction of abstraction, or at least the costs of abstraction, will tend to evolve.

81. In all of the four examples of the priority paradigm, of course, the debtor of the two secured parties did not have physical possession of the disputed property. 
For example, in a system of totally abstract rights a principle might develop to the effect that transferees who are first in time have priority over later, purported transferees of the same rights. Perhaps the chief advantage of this "first in time, first in right" principle is that it provides a decisional rule which promotes conflict resolution and judicial economy. It also reflects, and perhaps is better understood in terms of, the quasi-metaphysical notion that after a right is transferred to one person, there is nothing left to be transferred to a second party. ${ }^{82}$ (This notion would apply both to total rights and to partial rights like the interest of a secured party.) At any rate, the contribution which the "first in time, first in right" principle makes by itself to the reduction of both fraud and unfixity costs would appear to be marginal: given the limitations of oral information, even the most thorough investigation by a potential second party may fail to discover prior transfers.

A second class of principles that might be seen as evolving in order to circumvent some of the costs of a system of totally abstract rights are those based on sheer physical possession. Because physical possession lends at least some support-in a society where theft is a deviation rather than the norm-to the inference that the possessor has the right to the property, possessors may be given preferred status, vis-à-vis holders of abstract rights, in a variety of conflict situations. ${ }^{83}$

In general, the virtue of the possession principle is that a potential second secured party is put on notice of possible fraud if his proposed debtor is not in possession of the collateral in question. But the inadequacies of the possession principle are manifold. Intangible rights cannot be possessed, and thus could not be safely hypothecated in a system going no further along the road away from abstract rights than the adoption of the first-in-time and possession principles. More importantly, it is commercially desirable in many situations to allow debtors to retain possession of collateral needed in their business; if safe and virtually fraud-proof security interests not based on possession were achievable, financing possibilities in the general economy would be increased, with a beneficial effect on real output. Furthermore, the

82. Analysts at home with utilitarian modes of analysis may scorn this sort of reasoning, but conceptualistic notions, with their seemingly inevitable logic, surely have some independent force on legal reasoning-and it perhaps serves utility to let them have their way in the absence of countervailing considerations.

83. Note that such preference is likely to be curtailed in a society in which the legal possession and use of other people's property is a common and pervasive aspect of a complex economic system. Thus, rules of adverse possession in the Anglo-American legal system require the possessor to have been in possession for a considerable number of years, to have acted openly as owner rather than as lessee, bailee, pledgee, or thief, and to have satisfied a variety of other conditions of publicity and lack of ambiguity. 
possession principle as such does little to reduce unfixity costs; a secured party's possession of a debtor's property may keep the debtor from forgetting that he has indeed given the property as security to someone, but it will scarcely be an effective and fixed reminder of other details of the original secured transaction. Commercial society therefore inevitably evolves beyond the possession principle.

When rights to intangible property, or to tangible property not in possession of the owner, are at issue, what might be called the "paperizing principle" eventually comes into play. The problem of lack of verbal fixity is solved by embodying the abstract right in a fixed verbal formula written down on paper-a formula which, within the restraints imposed by the shifting nature of linguistic meaning itself, provides the same basic stimulus to all readers versed in the language. The basic stimulus may be interpreted and reacted to in different ways by different readers, of course, but the fixity of stimulus reduces the number and range of these variations.

An embryonic form of the paperizing principle at work is the Statute of Frauds. By requiring a writing between the parties to a transaction, unfixity costs are significantly reduced. Fraud costs ought also to be reduced, in that fraud by one of the parties on the other is made somewhat more difficult. At least a party will not be able easily to induce another into an agreement and then later claim-after it turns out that he has gotten the short end of the bargain-that there was no agreement. ${ }^{84}$ A Statute of Frauds will do little, however, to prevent fraud on successive transferees. The existence of a written security agreement between a debtor and a secured party will not benefit the potential second secured party whom the debtor wishes to defraud unless the potential secured party has knowledge of the prior agreement and access to an untampered original or an exact copy of it. If there are no legal rules to ensure that potential secured parties will have such knowledge and access, they may often be defrauded.

A more developed version of the paperizing principle is found in paper rights which uniquely embody abstract rights, for example, a note, a stock certificate, or a document of title. Only one piece of paper (or one set of papers, if the written material is lengthy) "really" embodies the abstract right; copies may be made, but they are just that"mere" copies of a note, certificate, etc., not "the" note or certificate.

84. If a party at the time of entering an agreement actually intends later to renege if to do so will be to his advantage, the later reneging can, I suggest, properly be labeled fraudulent. If one disregards subjective intentions, perhaps any reneging not occasioned by extraordinary circumstances could be called fraudulent. 
This practice of uniquely embodying rights, together with a standardization of forms of embodiment and the development of rules of transfer and negotiation, further reduces unfixity costs and facilitates the economical transfer of rights through a chain of transferees. Unfortunately, though, despite elaborate rules as to how fraud should be dealt with and who should suffer its consequences, embodiment does relatively little to reduce fraud costs. There are technical and legal impediments to the successful forging of checks and stock certificates, but they can be (and often are) overcome.

Be that as it may, in this stage of evolution of the tendency to suppress abstraction it becomes natural to accord some kind of preferred legal status to transferees who take possession of the paperized right. If, in a given sort of situation, the paperizing of rights becomes common and the elements of the paperization become fairly standard, possession of the paper is a sensible precaution to take. If $A$ 's right in some property is evidenced by a single piece of paper, a prudent buyer of the right will want to obtain the piece of paper so as to know exactly what his right consists of and to be able to demonstrate to future transferees what he can sell or hypothecate to them. If the buyer should pay for the right and not bother to obtain the paper, and if $A$ later sells the paper to a second innocent buyer, then the second buyer would be given priority in the right over the first, on the grounds that (1) he was more prudent and (2) the paperizing of such rights, since it performs useful economic and legal functions, is to be encouraged.

The same reasons could extend to the situation where the second transferee takes a paper right which was only created after the transfer of the right to the first transferee in abstract form. The basic priority paradigm analyzed earlier in this article is, of course, a situation of this kind. Though these remarks about the paperizing principle may suggest a general solution in favor of the holder of the paper rights, there is one additional step in the evolution of the tendency to suppress abstraction which casts doubt on such a result.

That step is the establishment of central recording or filing systems. ${ }^{85}$ Not only is the right paperized, but the paper right, a copy of it, or notice of it, is kept in a central ${ }^{86}$ system to which potential transferees can make reference. The most obvious examples are the real estate recording systems. Recording is then given preferred legal status:

85. This will, for example, prevent fraud on successive transferees, an area in which the Statute of Frauds was found wanting. See p. 476 supra.

86. If there is more than one office at which copies of the paper right or notice of it are kept, either special priority rules or special procedures to insure uniformity of records at the various offices are needed. 
a mortgagee can have an enforceable interest, vis-à-vis the owner who is his debtor, whether or not he records his interest, but he must record to protect himself against third parties. The recording system, in conjunction with such rules, probably reduces the overall amount of fraud that would otherwise result, forcing the fraudulently minded transferor who wants to conceal a prior adverse transfer to resort to attempts at bribing the recording officer or colluding with him.

The evolution of this "recording principle" clearly brings a number of advantages over the stage (not necessarily a temporally prior one) in which the paperizing principle and rules governing possession of tangible property were the only means of forwarding the policies behind the goal of eliminating abstraction. Of the doctrines and principles mentioned (the first-in-time principle, the possession principle, the paperizing principle as exemplified by the Statute of Frauds and various kinds of paper rights, and the recording principle), only the recording principle seems likely to achieve a substantial and decisive reduction of fraud costs. In addition, there is little a priori reason to believe that the costs of achieving the reduction will be exorbitant in relation to the costs of implementing the paperizing principle. Moreover, the recording principle ought to reduce unfixity costs just as well as the paperizing principle. A recording or filing system will reduce mistakes and confusion: the records will either contain, or provide a basis for obtaining, a written description of outstanding rights in the property in question, and a diligent putative transferee may discover that his transferor inadvertently failed to know about, or realize the significance and extent of, a prior adverse interest in the property. Finally, a recording system provides a basis for easily administrable judicial rules, since the recording system will definitively show which of a series of defrauded transferees of the same right was first in time to record. Thus, as a general theoretical matter, the recording principle seems to be the most advanced point in the evolution of the tendency to suppress abstraction, and it suggests a general solution to our priority paradigm (in favor of the first to file) opposite to that (in favor of the paper holder) suggested by the paperizing principle.

Returning from theory to statute, one readily perceives that the UCC provides a mixed system which utilizes-and to some extent synthesizes -all of the chief principles that have developed to reduce the costs of abstraction. The Code expresses, in $\S 9-312(5), 87$ a particular version of the virtually aboriginal first-in-time principle, though a reading of

87. Quoted in note 63 supra. 
the exceptions to the rule and of the many other rules of and relating to priority in Part 3 of Article 9 convinces one that the principle, in its general and unparticularized form, is virtually useless for the resolution of particular problems. The Code also employs the possession principle, both in making possession of collateral by the secured party an alternative to satisfying the Statute of Frauds ${ }^{88}$ in certain cases and by making possession a form of perfection of security interests in tangible collateral and in paper rights. ${ }^{80}$ The paperizing principle is reflected in Article 9's particular Statute of Frauds ${ }^{90}$ and in the recognition and great importance, exemplified by $\$ \S 9-308$ (a) and 9-309, that is given to paper rights. Finally, Article 9 is pervaded by references to and reliance upon its notice filing system-an inexpensive, streamlined, unified, widely used and highly successful expression of the recording principle-the mechanics of which are elaborately articulated in Part 4 of Article 9.

I have suggested throughout this inquiry that the paperizing principle is rooted in deep psychological needs as well as in more conventionally conceived commercial exigencies. The principle as manifested in practice seems to have acquired a strong and almost unshakeable grip on the thinking and the intuitive reactions of lawyers. But, given the existence of a thoroughly mixed system governing security interests, it is not at all obvious that the paperizing principle, which is a principle less advanced and less perfect than the recording principle, ought to be taken as an infallible rule for the solution of all priority problems involving paper rights. One must look instead for the priority rule which, within a mixed system and in a particular context of commercial practices and expectations, will most efficiently reduce fraud costs and unfixity costs.

\footnotetext{
88. See $\$ 9-203(1)(a)$.

89. See $\$ 9.305$.

90. See $\$ 9-203(1)(a)$.
} 